\title{
The Preference and Environmental Perception of Building Contour Control of Mountain-landscape City
}

\author{
Junru Zhou, Yuan Gao
}

\begin{abstract}
This paper focuses on the building contour control of mountain-landscape city based on the research of public preferences and environmental perceptions. Arousal and pleasure were selected as 2 key independent variables to measure the value of people's environmental perception. Layer-relationship, height-relationship, mountain contour, building contour, the relationship between building group and mountain contour and roof style are 6 spatial factors to characterize the urban skylines. 60 photos of real city scenes were used as the questionnaire materials, and 450 people who were the general public and some designers participated in the test. The main conclusions were drawn: (1) Preference shows a low correlation with arousal, but a high correlation with pleasure. Higher levels of arousal are linked with lower levels of pleasure. (2) Layer-relationship, height-relationship and roof style have great influence on public preferences. (3) Layer relationship, height relationship and the relationship between building group and mountain contour have stronger correlation with pleasure, but have less to do with arousal.
\end{abstract}

Keywords - preference; environmental perception; mountain-landscape City; skylines; building contour

\section{INTRODUCTION}

According to "2015 The World 's Best Skylines" list which was reported on the American famous architecture journal "The Almanac of Architecture and Design", the data shows that, 31 in the top 50 cities have natural mountain background. In other words, they are mountain-landscape cities. The natural mountain element is not only a inherent potential condition of a city, but also a basic carrier of the urban characteristics, and a major feature that distinguishes a city from the others. Defining a meaningful physical relationship between the changing urban environment and its natural setting is a complex task. The ups and downs of the mountain outline can contribute to build an echo relationship with the contour of urban construction elements, and can also serve as a background to enrich the layering of the urban skyline. Thus, the proper utilization of mountain setting is an important reason for the success of many excellent urban skyline design.

Junru Zhou, College / University Name: Southeast University, School of Architecture, P.R. China, E-mail address: junear1900@163.com

Yuan Gao, College / University Name: Southeast University, School of Architecture. P.R. China, E-mail address: $\underline{591768802 @ q q . c o m}$
TABLE I

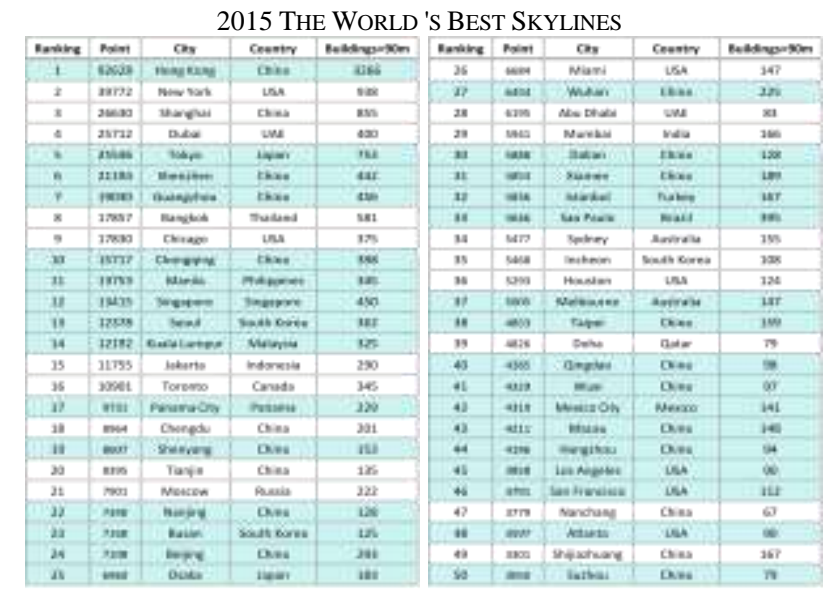

Almanac of Architecture \& Design 2014: Media Guide Edition (Almanac of Architecture and Design) [J]. 2015

The high speed development of the city requires enough building density and unit capacity to ensure its functions concentration and efficiency. And the development pressure makes the buildings become higher and higher. Thus, how to deal with the contradiction between the ever-growing buildings and the immovable mountain setting has become a great challenge to the urban design of mountain-landscape city. On the other hand, people who live in the city are the users of the urban landscape, and urban landscape influences their senses all the time. But in many cases, the public evaluation and judgment for the urban landscape are ignored in our city construction. Thus, urban designers must take the public environmental preferences and appeals into consideration. This paper attempts to explore the public preferences and environmental perception of building contour control and its influencing factors.

Some related researches which are based on the public perception preference of the landscape of urban skyline, have been already studied and practiced.

James A. Russell and Snodgras (1987), James A. Russell etc.(1989) identified "stimulation-pleasure" as the measure standard, and established the affect grid which evaluating the environment by using "excitement, stress, depression, relaxation".

Sheppard (1989), Arthur Stamps etc. (1993) pointed out that the image stimulation has many advantages, and the correlation index between the photo and the real scene can reach 
0.84. On this condition, most of the urban skyline evaluation program can use photos or slides as the scenario simulation.

Zacharias. J (1999) found that the skyline with natural element is more popular, and put forward that, in some conditions, limiting the height of buildings is more advantageous in improving the public preference perception than controlling the number of view corridors.

Tom Heath, etc. (2000) investigated that the visual complexity of high-rise buildings makes the change in the skyline by using the affect grid which based on the arousal-pleasure standard (Fig. 1). Moreover, they putted out that higher visual complexity of the building contour associated with higher perception, and the higher satisfaction at the same time.

Turkey's professor Cagri Imamoglu (2000) investigated the preference choices on the three levels of complexity of building facade sample pictures. Then pointed out that the complexity of the building appearance has a greater influence on the public perception. Particularly, the medium level of appearance complexity is easier to be popular. Furthermore, to some extent, the professional background of participators can influence the outcome of preference choices.

Chun-ming Chen (2001) tried to investigate how do the roof form and height of the tower building these two variable quantities impact the public environment perception and preferences results of the urban skyline. Based on that, he pointed out that the skyline with mixed, helm roof shape and higher attitude variation is more popular.

According to Arthur Stamps (2002), the three basic elements which can influence the quality of the urban skyline are the overall shape of the skyline, the number of the corner of the building contour and the difference of architecture properties. Then, further study showed (2005), the building properties (including height, width, depth, etc.) could influence the skyline preference of the participators more, and should be focused on when the design.

On the basis of Zacharias' research (1999), Leiqing Xu etc. (2013) finished a laboratory study which using artificial photos as stimulation. And finally demonstrated that preference for skylines shows a high correlation with complexity, arousal and pleasure perceived from the urban environment. And professional training was found to affect the preference and perception in the research.

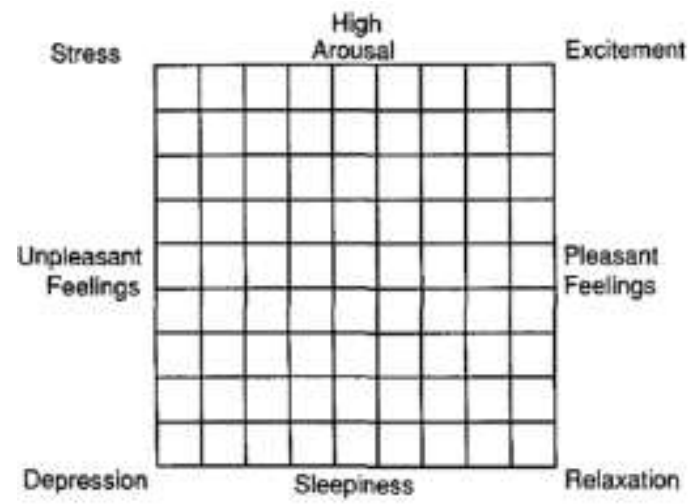

Fig. 1 Affect grid
Russell, J. A.,Weiss, A., \& Mendelsohn, G. A. (1989). Affect grid: A single-item scale of pleasure and arousal. Journal of Personality and Social Psychology, 57, 493-502.

To sum up, the current research on the urban skyline has three characteristics: the research of laboratory research using virtual scene model debugging (Zacharias, 1999), (Tom Heath, 2000) , (Cagri Imamoglu, 2000), (Arthur Stamps, 2002). The dependent variables are basic about preferences, complexity, stimulation and pleasure; The sample size was small, and college students were the majority participators.

\section{II.METHOD}

\section{A. Research Objective}

This research aims at public preference for urban skyline and its relation with the environmental perception and the building contour control of mountain-landscape city, seeking answers to the following questions:

(1) The correlation between public preference and environmental perception attributes.

(2) Spatial Factors that influence the public preference.

(3) The correlation between environmental perception attributes and spatial factors.

\section{B. Research Method}

In this study, urban photos were used as samples. According to the relevant researches, most of the quantitative researches of the urban skyline are based on the method of image stimulation, and mainly by using the laboratory researches which are based on the virtual scene model debugging. But there is no denying that the real scene is far more complicated than the virtual scene, and there are some unavoidably defects when applying the research conclusion to the reality control operation. So, this study use the urban real scene photos as research sample.

\section{Research Sample}

Select the typical mountain-landscape cities all around the world, and choose 60 urban skyline photos taken from the classical view points. Then, after the unified color processing and being cut into the same size, we finally get 60 photos as the research sample in order to reduce the interference of photos' color to preference judgment. The 60 photos were numbered 1 to 60 , and each 4 was divided into a group, the total 15 groups are recorded as one complete questionnaire. Then, disorder the existing order 4 times to form another 4 complete questionnaires. In the end, we get five sets of questionnaires, with each set contains 15 questionnaires, and each questionnaire contains 4 photos.

\section{Questionnaire Design}

In order to collect the public's preference value, environmental perception variable (arousal and pleasure) and possible spatial influence factors for the photos, the questionnaire mainly ask the following three questions:

(1) Choose your favorite skyline picture, and select or add the spatial influence factors (preference). 
(2) Choose a photo that you feel most stimulating (arousal)

(3) Choose a photo of that you feel most pleased with (Pleasure).

\section{E. Investigation Process}

The questionnaire survey used ipad to show only one questionnaire each time, so that the participator could make their choice. Firstly, the research asked participants to choose a favorite skyline photograph, and select or supplement the spatial factors which affecting their preference: layer-relationship, height-relationship, mountain contour, building contour, the relationship between building group and mountain contour and roof style. Secondly, the participants were then asked to select a picture of the urban skyline which was most stimulating or exciting (arousal) and a picture which was most pleasant (pleasure). In the process, the investigator should focus on the explanation of the two important concepts of "arousal" and "pleasure" in order to help the participator to understand and choose correctly. The investigation needs to be judged based on personal preference and the understanding of some semantic concepts, all the participators are required to have certain language understanding ability and urban landscape sensibility.

\section{F. Participators}

450 people who were the general public and some designers participated in the research, and between the ages of 18 to 60 . Among them, 246 female and 204 male participants accounting for $54.7 \%$ and $45.3 \%$ respectively, and 152 professional and 298 non professional participants taking up $33.8 \%$ and $66.2 \%$ respectively.

\section{RESULT AND ANALYSIS}

\section{A. Single Frequency Analysis}

The preference, arousal and pleasure scores of each photo sample are shown in table II. The "preference" was the total number of being chosen as "the favorite photo". Through data consolidation, we can find that the photo with the highest preference score is NO.26. It was chosen 20 times and the effective percentage is $22.2 \%$. The "arousal" was the total number of being chosen as "the most stimulating or exciting photo". We can find that the photo with the highest arousal score is NO.18. It was chosen 23 times and the effective percentage is $25.6 \%$. The "pleasure" was the total number of being chosen as "the most pleasant photo". We can find that the photo with the highest pleasure score is NO.26. And it was chosen 20 times and the effective percentage is $22.2 \%$.

TABLE II

THE PREFERENCE, AROUSAL AND PLEASURE SCORES

\begin{tabular}{|c|c|c|c|c|c|c|c|c|c|c|c|c|c|c|c|}
\hline No. & $\begin{array}{c}\text { preferenc } \\
\mathrm{e}\end{array}$ & $\begin{array}{c}\text { arousa } \\
1 \\
\end{array}$ & $\begin{array}{c}\text { pleasur } \\
\mathrm{e}\end{array}$ & No. & $\begin{array}{c}\text { preferenc } \\
\mathrm{e}\end{array}$ & $\begin{array}{c}\text { arousa } \\
1 \\
\end{array}$ & $\begin{array}{c}\text { pleasur } \\
\mathrm{e}\end{array}$ & No. & $\begin{array}{c}\text { preferenc } \\
\mathrm{e}\end{array}$ & $\begin{array}{c}\text { arousa } \\
1\end{array}$ & $\begin{array}{c}\text { pleasur } \\
\mathrm{e}\end{array}$ & No. & $\begin{array}{c}\text { preferenc } \\
\mathrm{e}\end{array}$ & $\begin{array}{c}\text { arousa } \\
1 \\
\end{array}$ & $\begin{array}{c}\text { pleasur } \\
\mathrm{e}\end{array}$ \\
\hline 1 & 15 & 5 & 15 & 16 & 4 & 2 & 9 & 31 & 6 & 3 & 6 & 46 & 2 & 19 & 1 \\
\hline 2 & 7 & 13 & 3 & 17 & 16 & 3 & 15 & 32 & 16 & 4 & 8 & 47 & 3 & 3 & 5 \\
\hline 3 & 0 & 5 & 3 & 18 & 6 & 25 & 4 & 33 & 2 & 4 & 3 & 48 & 4 & 2 & 1 \\
\hline 4 & 15 & 13 & 11 & 19 & 7 & 11 & 4 & 34 & 10 & 3 & 14 & 49 & 6 & 2 & 8 \\
\hline 5 & 12 & 19 & 3 & 20 & 2 & 14 & 1 & 35 & 3 & 15 & 1 & 50 & 1 & 12 & 3 \\
\hline 6 & 7 & 5 & 6 & 21 & 4 & 1 & 5 & 36 & 10 & 1 & 18 & 51 & 1 & 9 & 0 \\
\hline 7 & 14 & 22 & 2 & 22 & 3 & 17 & 3 & 37 & 10 & 4 & 12 & 52 & 6 & 0 & 12 \\
\hline 8 & 5 & 3 & 6 & 23 & 1 & 5 & 3 & 38 & 7 & 15 & 8 & 53 & 11 & 16 & 8 \\
\hline 9 & 16 & 4 & 17 & 24 & 7 & 5 & 4 & 39 & 3 & 4 & 8 & 54 & 10 & 3 & 7 \\
\hline 10 & 4 & 5 & 10 & 25 & 0 & 0 & 1 & 40 & 16 & 20 & 4 & 55 & 8 & 19 & 8 \\
\hline 11 & 5 & 20 & 3 & 26 & 20 & 2 & 20 & 41 & 6 & 1 & 3 & 56 & 9 & 5 & 8 \\
\hline 12 & 7 & 5 & 14 & 27 & 17 & 4 & 18 & 42 & 1 & 2 & 1 & 57 & 4 & 11 & 2 \\
\hline 13 & 14 & 3 & 14 & 28 & 10 & 1 & 14 & 43 & 7 & 1 & 3 & 58 & 4 & 3 & 6 \\
\hline 14 & 16 & 6 & 12 & 29 & 5 & 3 & 11 & 44 & 4 & 2 & 9 & 59 & 6 & 4 & 9 \\
\hline 15 & 11 & 23 & 4 & 30 & 18 & 3 & 13 & 45 & 0 & 3 & 4 & 60 & 4 & 2 & 9 \\
\hline
\end{tabular}

arousal and pleasure on preference score. As the table IVshows,

\section{B. Ranking Analysis}

Firstly, extracting the top 10 in preference, arousal and pleasure ranking, and trying to seek for the influence of arousal and pleasure on preference score. As table III shows, among the top 10 of the preference ranking, we get 1 in the top 10 of the arousal ranking, and 5 in the top 10 of the pleasure ranking at the same time. Secondly, extracting the top 20 in preference, arousal and pleasure rank, and trying to seek for the influence of among the top 20 of the preference ranking, we get 6 in the top 20 of the arousal ranking, 12 in the top 20 of the pleasure ranking, and 1 in all the ranking chart at the same time. It's obvious that the effect of pleasure on the preference score is slightly bigger than arousal. 
TABLE III

THE TOP 10 IN PREFERENCE, AROUSAL AND PLEASURE RANKING

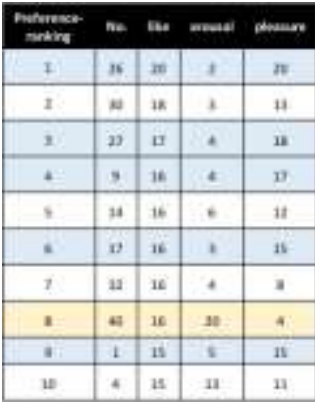

\begin{tabular}{|c|c|c|}
\hline Naminty & $=$ & waroming \\
\hline 3 & III & \\
\hline 2 & w & \\
\hline 3 & 7 & \\
\hline 4 & 4 & $\cdot$ \\
\hline 5 & 14 & \\
\hline 1 & , & \\
\hline 7 & n & \\
\hline 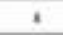 & * & \\
\hline, & 32 & \\
\hline$\omega$ & 3 & \\
\hline
\end{tabular}

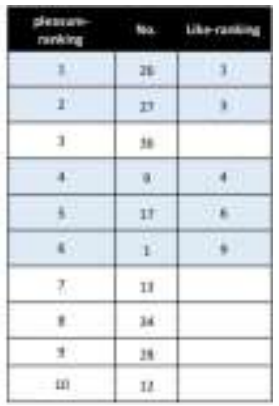

TABLE IV

THE TOP 20 IN PREFERENCE, AROUSAL AND PLEASURE RANKING
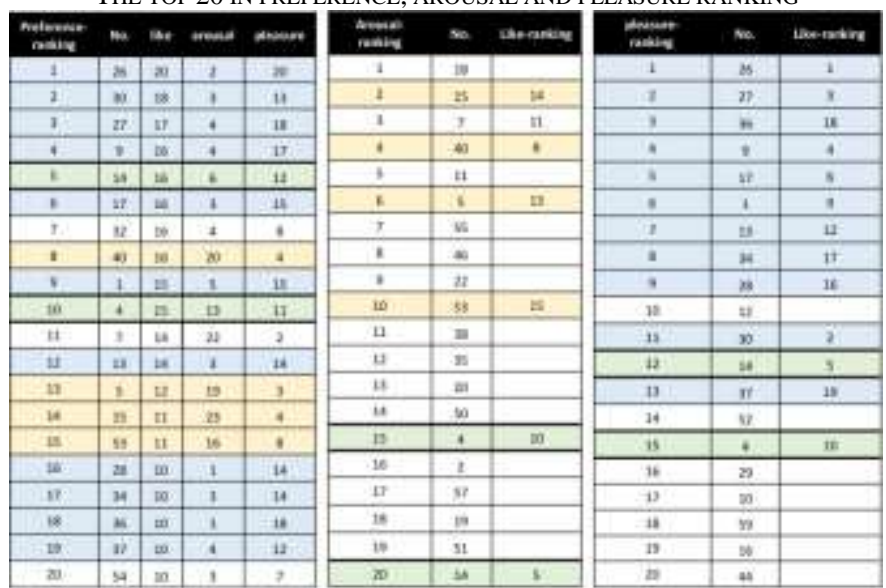

\section{Ratio Analysis}

Among the participators, there were 95 people who choose the most stimulating or exciting photos and favorite photos are the same, and they accounting for $21.11 \%$ of the total number of the participators. 227 people who choose the most pleasant photos and favorite photos are the same, and they accounting for $50.40 \%$ of the total. Then, as for the others, whose favorite photos are neither the one they feel the most stimulating nor the one they feel the most pleasant. As the figure 5 shown. So, the effect of the pleasure on the preference score is slightly higher than arousal.

\section{Correlation Analysis}

\section{(1) Preference - Arousal - Pleasure}

Table V shows the results of the correlation analysis between preference, arousal and pleasure. Preference is slight positively correlated with arousal, but the correlation coefficient is only 0.051. Preference is moderate positively correlated with pleasure, and the correlation coefficient is $0.666(\mathrm{p}<0.01)$. Arousal is moderate negatively correlated with pleasure, and the correlation coefficient is $0.407(\mathrm{p}<0.01)$. Thus, the public perception of arousal has little impact on its preference choice. Higher pleasure score is associated with higher preference score, and higher arousal score leads to lower pleasure score at the same time.
TABLE V

THE CORRELATION ANALYSIS BETWEEN PREFERENCE, AROUSAL AND PLEASURE

\begin{tabular}{|c|c|c|c|c|}
\hline copy & More table copya & $\begin{array}{l}\text { preferenc } \\
\mathrm{e}\end{array}$ & arousal & pleasure \\
\hline \multirow[t]{2}{*}{$\begin{array}{l}\text { preferenc } \\
\mathrm{e}\end{array}$} & $\begin{array}{ll}\text { Pearson } & \text { correlation } \\
\text { coefficient } & \end{array}$ & 1 & 0.051 & $0.666^{* *}$ \\
\hline & Sig.(2-tailed) & & 0.698 & 0 \\
\hline \multirow[t]{2}{*}{ arousal } & $\begin{array}{l}\text { Pearson } \\
\text { coefficient }\end{array}$ & 0.051 & 1 & $-0.407 * *$ \\
\hline & Sig.(2-tailed) & 0.698 & & 0.001 \\
\hline \multirow[t]{2}{*}{ plesure } & $\begin{array}{l}\text { Pearson correlation } \\
\text { coefficient }\end{array}$ & $0.666^{* *}$ & $-0.407 * *$ & 1 \\
\hline & Sig.(2-tailed) & 0 & 0.001 & \\
\hline
\end{tabular}

\section{(2) Preference - Spatial Factors}

Preference is selected as the dependent variable, and 6 spatial factors are selected as independent variables. Trying to seek for what factors will lead to higher preference through correlation analysis. As the table VI shows, there is a high positive correlation between preference and 6 spatial factors $(p<0.01)$. Among which, preference has the highest positive correlation with layer-relationship, and the correlation coefficient reaches 0.895 ( $p<0.01$ ). Secondly is the positive correlation between preference and height-relationship, and the correlation coefficient reaches $0.837(\mathrm{p}<0.01)$. Next is the correlation between preference and roof style, and the positive correlation coefficient reaches 0.848 ( $\mathrm{p}<0.01)$. In conclusion, layer-relationship, height-relationship and roof style have greater influence on public preference choice.

\section{(3) Arousal - Pleasure - Spatial Factors}

Arousal and pleasure are selected as the dependent variable, and 6 spatial factors are selected as independent variables. Trying to seek for what factors will lead to higher arousal and pleasure through correlation analysis. As the table VII shows, there is a lower correlation between arousal and 6 spatial factors. Among which, arousal has the lower positive correlation with the relationship between building group and mountain contour, and the correlation coefficient is $0.246(\mathrm{p}=0.058)$. At the same time, there is a higher positive correlation between pleasure and 6 factors. Among which, pleasure has the highest positive correlation with layer-relationship, and the correlation coefficient reaches 0.718 $(\mathrm{p}<0.01)$. Secondly is the positive correlation between pleasure and mountain contour, and the correlation coefficient reaches $0.630(\mathrm{p}<0.01)$. In a word, layer-relationship and mountain contour have greater influence on public pleasure choice, and all factors have a weak effect on public arousal choice.

\section{DISCUSSION}

This study gives us the following three conclusions:

(1) Preference shows a lower correlation with arousal, but a higher correlation with pleasure. Higher pleasure score is associated with higher preference score, but higher arousal score is linked with lower pleasure score.

(2) layer-relationship, height-relationship and roof style have greater influence on public preference choice. Urban designers 
should focus on the control of the above three factors.

(3) layer-relationship and mountain contour have greater influence on public pleasure choice, and all factors have a weak effect on public arousal choice. We need to strengthen the selection of the tower building and the control of its height. And the coverage relation between the building layer and the

\section{TABLE V}

THE CORRELATION ANALYSIS BETWEEN PREFERENCE AND SPATIAL FACTORS

\begin{tabular}{|c|c|c|c|c|c|c|c|c|c|}
\hline & & arousal & pleasure & $\begin{array}{l}\text { layer } \\
\text { relationship }\end{array}$ & $\begin{array}{l}\text { height } \\
\text { relationship }\end{array}$ & $\begin{array}{l}\text { mountain } \\
\text { contour }\end{array}$ & $\begin{array}{l}\text { building } \\
\text { contour }\end{array}$ & $\begin{array}{c}\text { relationship between } \\
\text { building group and } \\
\text { mountain contour }\end{array}$ & $\begin{array}{l}\text { roof } \\
\text { style }\end{array}$ \\
\hline \multirow[t]{2}{*}{ arousal } & $\begin{array}{c}\text { Pearson } \\
\text { correlation } \\
\text { coefficient }\end{array}$ & 1 & $-0.352^{* *}$ & 0.069 & 0.213 & -0.067 & 0.144 & 0.246 & 0.065 \\
\hline & Sig.(2-tailed) & & 0.006 & 0.061 & 0.102 & 0.612 & 0.271 & 0.058 & 0.624 \\
\hline \multirow[t]{2}{*}{ pleasure } & $\begin{array}{l}\text { Pearson } \\
\text { correlation } \\
\text { coefficient } \\
\end{array}$ & $-0.352^{* *}$ & 1 & $0.718 * *$ & $0.509 * *$ & $0.630 * *$ & $0.591 * *$ & $0.454 * *$ & $0.582 * *$ \\
\hline & Sig.(2-tailed) & 0.006 & & 0 & 0 & 0 & 0 & 0 & 0 \\
\hline \multirow[t]{2}{*}{ layer relationship } & $\begin{array}{c}\text { Pearson } \\
\text { correlation } \\
\text { coefficient }\end{array}$ & 0.069 & $0.718^{* *}$ & 1 & $0.827 * *$ & $0.737 * *$ & $0.769 * *$ & $0.740 * *$ & $0.769 * *$ \\
\hline & Sig.(2-tailed) & 0.601 & 0 & & 0 & 0 & 0 & 0 & 0 \\
\hline \multirow[t]{2}{*}{ height relationship } & $\begin{array}{c}\text { Pearson } \\
\text { correlation } \\
\text { coefficient }\end{array}$ & 0.213 & $0.509 * *$ & $0.827 * *$ & 1 & $0.726 * *$ & $0.622 * *$ & $0.786^{* *}$ & $0.783^{* *}$ \\
\hline & Sig.(2-tailed) & 0.102 & 0 & 0 & & 0 & 0 & 0 & 0 \\
\hline \multirow[t]{2}{*}{ mountain contour } & $\begin{array}{c}\text { Pearson } \\
\text { correlation } \\
\text { coefficient } \\
\end{array}$ & -0.067 & $0.630^{* *}$ & $0.737 * *$ & $0.726^{* *}$ & 1 & $0.568 * *$ & $0.499 * *$ & $0.742 * *$ \\
\hline & Sig.(2-tailed) & 0.612 & 0 & 0 & 0 & & 0 & 0 & 0 \\
\hline \multirow[t]{2}{*}{ building contour } & $\begin{array}{l}\text { Pearson } \\
\text { correlation } \\
\text { coefficient } \\
\end{array}$ & 0.144 & $0.591 * *$ & $0.769 * *$ & $0.622 * *$ & $0.568 * *$ & 1 & $0.601 * *$ & $0.732 * *$ \\
\hline & Sig.(2-tailed) & 0.271 & 0 & 0 & 0 & 0 & & 0 & 0 \\
\hline \multirow[t]{2}{*}{$\begin{array}{c}\text { relationship between } \\
\text { building group and } \\
\text { mountain contour }\end{array}$} & $\begin{array}{c}\text { Pearson } \\
\text { correlation } \\
\text { coefficient }\end{array}$ & 0.246 & $0.454 * *$ & $0.740 * *$ & $0.786 * *$ & $0.499 * *$ & $0.601 * *$ & 1 & $0.712 * *$ \\
\hline & Sig.(2-tailed) & 0.058 & 0 & 0 & 0 & 0 & 0 & & 0 \\
\hline \multirow[t]{2}{*}{ roof style } & $\begin{array}{c}\text { Pearson } \\
\text { correlation } \\
\text { coefficient } \\
\end{array}$ & 0.065 & $0.582 * *$ & $0.769 * *$ & $0.783 * *$ & $0.742 * *$ & $0.732 * *$ & $0.712 * *$ & 1 \\
\hline & Sig.(2-tailed) & 0.624 & 0 & 0 & 0 & 0 & 0 & 0 & \\
\hline
\end{tabular}

TABLE VII

THE CORRELATION ANALYSIS BETWEEN AROUSAL, PLEASURE AND SPATIAL FACTORS

\begin{tabular}{|c|c|c|c|c|c|c|c|c|}
\hline & & preference & $\begin{array}{l}\text { layer } \\
\text { relationship }\end{array}$ & $\begin{array}{l}\text { height } \\
\text { relationship }\end{array}$ & $\begin{array}{l}\text { mountain } \\
\text { contour }\end{array}$ & $\begin{array}{l}\text { building } \\
\text { contour }\end{array}$ & $\begin{array}{c}\text { relationship between } \\
\text { building group and } \\
\text { mountain contour }\end{array}$ & $\begin{array}{l}\text { roof } \\
\text { style }\end{array}$ \\
\hline \multirow[t]{2}{*}{ preference } & $\begin{array}{c}\text { Pearson correlation } \\
\text { coefficient }\end{array}$ & 1 & $0.895^{* *}$ & $0.666^{* *}$ & $0.770 * *$ & $0.792 * *$ & $0.807 * *$ & $0.848 * *$ \\
\hline & Sig.(2-tailed) & & 0 & 0 & 0 & 0 & 0 & 0 \\
\hline \multirow[t]{2}{*}{ layer relationship } & $\begin{array}{c}\text { Pearson correlation } \\
\text { coefficient }\end{array}$ & $0.895^{* *}$ & 1 & $0.827 * *$ & $0.737 * *$ & $0.769 * *$ & $0.740 * *$ & $0.769 * *$ \\
\hline & Sig.(2-tailed) & 0 & & 0 & 0 & 0 & 0 & 0 \\
\hline \multirow[t]{2}{*}{ height relationship } & $\begin{array}{c}\text { Pearson correlation } \\
\text { coefficient }\end{array}$ & 0.873 ***** & $0.827 * *$ & 1 & $0.726 * *$ & $0.622 * *$ & $0.786^{* *}$ & $0.783 * *$ \\
\hline & Sig.(2-tailed) & 0 & 0 & & 0 & 0 & 0 & 0 \\
\hline \multirow[t]{2}{*}{ mountain contour } & $\begin{array}{c}\text { Pearson correlation } \\
\text { coefficient }\end{array}$ & $0.770 * *$ & $0.737 * *$ & $0.726^{* *}$ & 1 & $0.568 * *$ & $0.499 * *$ & $0.742 * *$ \\
\hline & Sig.(2-tailed) & 0 & 0 & 0 & & 0 & 0 & 0 \\
\hline \multirow[t]{2}{*}{ building contour } & $\begin{array}{c}\text { Pearson correlation } \\
\text { coefficient }\end{array}$ & $0.792 * *$ & $0.769 * *$ & $0.622 * *$ & $0.568 * *$ & 1 & $0.601 * *$ & $0.732 * *$ \\
\hline & Sig.(2-tailed) & 0 & 0 & 0 & 0 & & 0 & 0 \\
\hline
\end{tabular}




\begin{tabular}{|c|c|r|r|r|r|r|r|}
\hline $\begin{array}{c}\text { relationship between } \\
\text { building group and } \\
\text { mountain contour }\end{array}$ & $\begin{array}{c}\text { Pearson correlation } \\
\text { coefficient }\end{array}$ & $0.807^{* *}$ & $0.740^{* *}$ & $0.786^{* *}$ & $0.499^{* *}$ & $0.601^{* *}$ & $0.712^{* *}$ \\
\hline roof style & $\begin{array}{c}\text { Searson correlation } \\
\text { coefficient }\end{array}$ & $0.848^{* *}$ & $0.769^{* *}$ & $0.783^{* *}$ & $0.742^{* *}$ & $0.732^{* *}$ & 0 \\
\hline & Sig.(2-tailed) & 0 & 0 & 0 & 0 & 0 & $0.712^{* *}$ \\
\hline
\end{tabular}

\section{REFERENCES}

[1] Arnheim, R. Art and Visual Perception[M]. London: Cambridge University Press. 1954.

[2] Arnheim, R. Visual Thinking[M]. Berkeley: University of California Press. 1969.

[3] Kevin Lynch. The Image of the City[M]. Cambridge Massachussettes: MIT Press. 1959

[4] Ittelson, W.H. Visual Space Perception[M]. New York: Springer. 1960.

[5] Simon Bell. Elements of Visual Design in the Landscape[M]. Spon Press. 1993.

[6] Russell, J. A., \& Snodgrass, J. Emotion and the environment. In D. Stokols \& I. Altman (Eds.), Handbook of environmental psychology (pp. 244-280). New York: John Wiley. 1987.

[7] Russell, J. A.,Weiss, A., \& Mendelsohn, G. A. (1989). Affect grid: A single-item scale of pleasure and arousal. Journal of Personality and Social Psychology, 57, 493-502.

[8] Sheppard S R J. Visual simulation-a user's guide for architects, engineers, and planners [M]. New York: Van Nostrand Reinhold, 1989.

[9] Arthur Stamps I I I, Simulation Effects on Environmental Preference[J]. Journal of Environmental Management: 1993(38): 115-132.

[10] Zacharias J. Preferences for View Corridors Through the Urban Environment[J]. Landscape and Urban Planning. 1999(43): 217-225.

[11] Tom Heath, Sandy G. Smith,Bill Lim. Tall Buildings and the Urban Skyline The Effect of Visual Complexity on Preference[J]. Environment and Behavior, Vol. 32 No. 4, 2000 (July):541-556.

[12] Cagri Imamoglu. Complexity, Linking and Familiarity-Imamoglu[J]. Journal of Environmental Psychology 2000(20):5-16.

[13] Stamps A.E. Fractals, Skylines, Nature and Beauty [J]. Landscape and Urban Planning, 2002,60(3):163-184.

[14] Stamps A.E., Nasar J L, Hanyu K. Using Pre-construction Validation to Regulate Urban Skylines[J]. Journal of the American Planning Association, 2005,71(1):73-91.

[15] 陈俊铭,林宴州. 民众对都市天际线景观知觉与偏好之研究. 台湾: 都市与计划, 2001, 28(3): 367-386.

[16] 徐否青, 周峰, 吴人韦. 山景城市天际线的偏好与景观知觉一一建筑高 度与视廊数量的影响. 中国园林, 2013 (10): 46-52. 